

\section{Daftar Isi (Table of Content) Journal of Government
Civil Society}

\begin{tabular}{|c|c|}
\hline \multirow{3}{*}{$146-163$} & $\begin{array}{l}\text { New Public Management (New Public Comparison Meta-Analysis } \\
\text { Developed and Developing Country Policies) }\end{array}$ \\
\hline & Dyah Mutiarin $^{2}$, Misran ${ }^{1}$ \\
\hline & $\begin{array}{l}\text { (1 Department of Government Affairs and Administration, Universitas Muhammadiyah } \\
\text { Yogyakarta, Indonesia) } \\
\text { (2 Jusuf Kalla School of Government, Universitas Muhammadiyah Yogyakarta, Indonesia) }\end{array}$ \\
\hline \multirow{3}{*}{$164-183$} & $\begin{array}{l}\text { Policy Networks: Actors, Interests, and Power Relations in the Jakarta } \\
\text { Reclamation Project }\end{array}$ \\
\hline & Rizki Hegia Sampurna1,2, Chih-Chieh Chou ${ }^{1}$ \\
\hline & $\begin{array}{l}\text { (' Department of Political Science, National Cheng Kung University (NCKU), Taiwan) } \\
\text { ('2 Department of Public Administration, Universitas Muhammadiyah Sukabumi (UMMI), } \\
\text { Indonesia) }\end{array}$ \\
\hline \multirow{3}{*}{$184-197$} & $\begin{array}{l}\text { National Insights and Youth Political Attitudes in Rural Lampung Against } \\
\text { Negative Campaign }\end{array}$ \\
\hline & Hertanto $^{1}$, Handi Mulyaningsih ${ }^{2}$, Asep Nurjaman ${ }^{3}$ \\
\hline & $\begin{array}{l}\left({ }^{1} \text { Departement of Government Science, Universitas Lampung, Indonesia) }\right. \\
\left({ }^{2} \text { Departement of Sociology, Universitas Lampung, Indonesia) }\right. \\
\left({ }^{3} \text { Departement of Government Science, Universitas Muhammadiyah Malang, Indonesia) }\right.\end{array}$ \\
\hline \multirow{3}{*}{$198-213$} & $\begin{array}{l}\text { Ethnic Identity and Local Politics: Study on Regional Head Election in } \\
\text { Merauke Regency } 2020\end{array}$ \\
\hline & Misran', Wahdania Sardi' ${ }^{1}$, Zuly Qodir ${ }^{1}$ \\
\hline & $\begin{array}{l}\text { (1 Department of Government Affairs and Administration, Jusuf Kalla School of Government, } \\
\text { Universitas Muhammadiyah Yogyakarta, Indonesia) }\end{array}$ \\
\hline \multirow{3}{*}{$214-236$} & $\begin{array}{l}\text { Stakeholder Collaboration Model for Ecotourism Development: A Case } \\
\text { Study from Batu City, East Java Province }\end{array}$ \\
\hline & 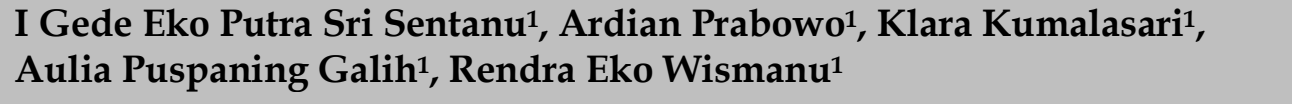 \\
\hline & (' Departement of Public Administration, Universitas Brawijaya, Indonesia) \\
\hline
\end{tabular}


Farmers Social Movement Studies: A Systematic Literature Review for A Conceptual Model

$237-262 \quad$ Wahyudi $^{1}$

(' Department of Sociology, Universitas Muhammadiyah Malang, Indonesia)

Factors Affecting Trust in E-Government

Ulung Pribadi' ${ }^{1}$, Muhammad Iqbal ${ }^{2}$, Fittia Restiane ${ }^{3}$

263 - 276 (1 Post-Graduate Program Universitas Muhammadiyah Yogyakarta, Indonesia)

( ${ }^{2}$ Department of Political Science National Cheng Kung University, Taiwan)

$\left({ }^{3}\right.$ Department of Government Affairs and Administration Universitas Muhammadiyah Yogyakarta, Indonesia) 


\title{
New Public Management (New Public Comparison Meta-Analysis Developed and Developing Country Policies)
}

\author{
Dyah Mutiarin $^{1,2^{*}}$, Misran $^{1}$ \\ ${ }^{1}$ Department of Government Affairs and Administration, Universitas Muhammadiyah Yogyakarta, \\ Indonesia \\ ${ }^{2}$ Jusuf Kalla School of Government, Universitas Muhammadiyah Yogyakarta, Indonesia \\ *Email Correspondence: mutiarin@umy.ac.id
}

\begin{abstract}
This study aims to determine the development of research on new public management policies in developed and developing countries in the last five years. To find out, we reviewed hundreds of related journals related to new general management policies in developed and developing countries with previous 5-year edition from 2016 to 2020. Then we compared the concepts used in new public management in developed and developing countries. This study used a qualitative research method with a review of previous research. Sources are selected articles published in the Scopus database in the last five years, from 2016 to 2020. Selected items are publications relevant to new public management policy topics in developed and developing countries. This study's results were obtained through a data analysis process using the Nvivo 12 Plus and VOSviwer applications. The results showed 90 concepts in studying new public management policies in developed countries and categorized them into five groups. Again, new public management policies in developing countries have 58 concepts and can be categorized into four groups. The significance of this research is the discovery of mapping new public management policy concepts in developed and developing countries to assist in developing a conceptual framework in subsequent studies and can see the novelty in further research.
\end{abstract}

Keywords: New public management, public policy in developed countries, public policy in developing countries, scopus

\begin{abstract}
ABSTRAK
Penelitian ini bertujuan untuk mengetahui perkembangan penelitian pada tema kebijakan manajemen publik baru di negara maju dan negara berkembang dalam kurung waktu lima tahun terakhir. Untuk mengetahuinya, kami mereview ratusan jurnal terkait kebijakan manajemen publik baru di negara maju dan negara berkembang dengan edisi lima tahun sebelumnya dari tahun 2016 sampai dengan 2020. Kemudian membandingkan konsep yang digunakan pada manajemen publik baru di negara maju dan negara berkembang. Penelitian ini menggunakan metode kualitatif dengan mereview dari penelitian sebelumnya. Sumber dipilih yang diterbitkan di data base scopus dalam lima tahun terakhir, dari 2016 hingga 2020. Artikel yang dipilih adalah publikasi yang relevan dengan topik kebijakan manajemen publik baru di negara maju dan negara berkembang. Hasil penelitian ini diperoleh melalui proses analisis data menggunakan Aplikasi Nvivo 12 dan VOSviwer. Hasil penelitian menunjukkan bahwa terdapat 90 konsep dalam kajian kebijakan manajemen publik baru di negara maju dan dapat dikategorikan menjadi lima kelompok. Selanjutnya kebijakan manajemen publik baru di negara berkembang terdapat lima puluh delapan konsep dan dapat di kategorikan menjadi empat kelompok. Signifikansi penelitian ini adalah ditemukannya pemetaan konsep kebijakan manajemen publik baru di negara maju dan negara berkembang sehingga dapat membantu dalam pengembangan kerangka konseptual pada kajian-kajian selanjutnya serta dapat melihat kebaruan dalam meneliti selanjutnya.
\end{abstract}

Kata Kunci: Manajemen publik baru, kebijakan publik di negara maju, kebijakan publik di negara berkembang, scopus

Citation : Mutiarin, D., \& Misran. (2021). New Public Management (New Public Comparison MetaAnalysis Developed and Developing Country Policies). Journal of Government and Civil Society, 5(2), 145-163. https://doi.org/10.31000/jgcs.v5i2.3969 


\section{INTRODUCTION}

Over the last two decades, public management has undergone substantial changes in developed and developing countries (Kharisma, 2014). Modern administrative systems emerged in the nineteenth century to the 1960s (Rushananto, 2014, Hood \& Dixon, 2015, Waheduzzaman, 2019). The new public management has become the dominant ideology of political and administrative reform in developed countries. Moreover, this trend then spread to developing countries and has made a tremendous contribution to public sector reform. New public management was formed because of the weakness of the bureaucratic paradigm in public Administration. The primary practitioners of new public management (NPM) were British, under Margaret Thatcher, the then Prime Minister. United States municipal governments also adopted NPM due to the heavy damage caused by the tax rebellion. The economic recession government's interventionist character is quite visible in production, provision, and regulation activities. This interventionist state's characteristics were put forward by Max Weber with solid echoes from other scholars (Indraddin, 2016). The dichotomy of policy administration, rule-based Administration, meritocracy, career systems, impersonality, labor division, and hierarchy are essential characteristics (Raharjanto, 2019). The contributions of the old system were enormous. However, since the 1970s, the senior administrative model has come under heavy criticism for various reasons (Alamsyah, 2016).

The emergence of a new public management model (NPM) Common and Minogue observed that the government's fiscal crisis, the poor performance of the public sector in various arenas, arrogant bureaucracy, lack of accountability, corruption, changing public expectations, and the emergence of more alternative forms of service delivery both have contributed to the emergence of the NPM model. Whatever the reasons for its emergence, this new model promises leaner and better governance, decentralization, empowerment, customer satisfaction, and better public accountability mechanisms (Pedersen \& Wilkinson, 2018, Zhong \& Fisher, 2017). Public services must pay attention to more than just the market. It must also be laws and the constitution, societal values, political norms, professional standards, and citizens' interests. Public accountability must be built to develop a multi-cultural society consensus has emerged, indicating a partnership between the state, the private sector, and civil society organizations in various activities (Rosyadi \& Dharma, 2014). The goal is to alleviate excessive government burdens and involve other parties who are more efficient in producing goods and services and providing them to the public (Prabowo, 2018)

There is no doubt that the traditional public administration model played a historic role in many countries' economic transformation, including some in the developing world. However, despite his contribution, the pressure has been under constant pressure since the mid-1970s. The first set of criticisms focuses on major economic issues. The government is too big. It uses up existing resources; the government is involved in too many of these 
activities, whereas alternative means of provision exist for many of these activities; and. Increased inflation, high costs, and excessive bureaucracy due to state intervention. There have been calls to "reinvent" government based on a market economy. Expressed in economic terms, this formula is reported by the World Bank, the International Monetary Fund, the Organization for Economic Cooperation and Development, etc. It is also a powerful instrument for change in developing countries, receiving a prescription from international donors for financial assistance. The second aspect of criticism relates to the implementation pattern. This traditional administrative model was rejected because it was considered inefficient, expensive, rigid, corrupt, irresponsible, and unsuitable for an era looking for a more dynamic social and economic development (Taufiqurokhman \& Satispi, 2018)

Undoubtedly many developing countries are experimenting with new public management reforms. There are some well-known examples: Malaysia's experiment with total quality management (Tampubolon, 2020), results-oriented management initiatives in Uganda, and the massive restructuring of Chilean education along market lines internally, a change that was far more radical than that had been done in the UK (Lim et al., 2020). The UK is considered a developing country for NPM and a launching point for NPM worldwide due to its significant contribution to the development of NPM. After its emergence, NPM was quickly embraced in several countries, especially in North America and Australia, due to NPM reforms for International Financial Institutions and OECD countries in developing countries (Ikeanyibe, 2016). In Singapore's case, this country has special economic, political, and social conditions contributing to the successful implementation of NPM reforms (W Waheduzzaman, 2019). Singapore is a small country compared to many other Asian countries. This is a driving factor in increasing economic growth rapidly to compete with other countries in the region (Ikeanyibe, 2016). The government of Bangladesh, for example, adopted NPM to improve public services at the local level. Other public management features in developing countries, notably the continuation of 'traditional' public Administration and the Adoption of the 'Washington model' of civil service reform.

This study will compare the concepts of developed and developing countries in implementing new public management. The new public management has become the dominant ideology of political and administrative reform in the developed world. Moreover, this trend then spread to developing countries and has made a tremendous contribution to public sector reform. A vital aspect of this argument suggests that the new public management identifies and changes traditional public management's weaknesses. Therefore, it becomes a new paradigm for sector management reform, and hence a new paradigm for sector reform. 
Several previous researchers have carried out this study by conducting research mapping with specific topics. Husna, Kusumasari, \& Pramusinto worked on research mapping on the concept of "network" in public Administration from 2007-2016 from articles in journals indexed by Scopus, and 111 papers were obtained (Prabowo, 2018). In entrepreneurship (Heidari, Yazdanparast, \& Jabbarzadeh, 2019), Research mapping was carried out on 947 academic documents from 1972-2019. Research using bibliometric cartography analysis was carried out on the concept of absorptive capacity for 25 years. There are 336 articles analyzed using HisCite and 2088 using VosViewer (Apriliyanti \& Alon, 2017), mapping bureaucratic reform research in Indonesia research mapping of bureaucratic reform in Indonesia (Habibi, 2020). Mapping research on a topic has been carried out in various disciplines. The goal is to see the development (dynamics) of the study at a specific time and provide an overview of the dynamics/journey of a particular theme discussed in the research. Mapping can also classify concepts and theories that get the most attention from researchers. This research is also a literature review of new public management policies in developed and developing countries.

\section{METHODS}

This study aims to examine various scientific articles that discuss new public management policies in developed and developing countries that have been published in Scopus. Besides, the review article in this study is directed at conceptualizing the survey of new public management policies in developed and developing countries, which is explained through the following questions, namely: (1) What are the topics related to the study of new public management policies in developed countries and developing countries? (2) What types of mapping are used in new public management policy topics in developed and developing countries? (3) What concepts are used in the study of new public management policies in developed and developing countries? These questions are explained based on the topic of study, the framework, and previous research findings indexed in the Scopus database. The articles reviewed in this study go through the stages of (1) searching for items, (2) mapping topics, (3) analyzing issues, and (4) conceptualizing new public service management policies in developed and developing countries.

Articles are searched through the following stages. First, identify the theme. This is done using the Scopus database. Furthermore, at this stage, the keywords "new public service management policies in developed countries" "New public management policies in developing countries" are entered in the search column for articles on Scopus, and the year of publication is limited between 2016 and 2020. The search resulted in 743 views. For developed countries and 145 for developing countries, the articles are relevant to the topic. The publications accessed, visualization, and bibliometric mapping were carried out through VOSviewer software (Anglada-Tort \& Sanfilippo, 2019), and bibliometric 
(Heidari et al., 2019). This study analyzes data collected via VOSviewer, and N Vivo, similar to those suggested by (Oscar Basulto, Pablo Segovia, \& Cristián Jullian, 2020) and (Cumming \& Johan, 2019). Furthermore, bibliometric analysis is identical to that recommended by (Anglada-Tort \& Sanfilippo, 2019), And (Mørk, 2020) applied.

This process is carried out to obtain data clusters and visualize networks from the research theme. While the Nvivo 12 plus software is used to input learning topics, namely the relationship of study themes and their mapping based on the focus of each article analyzed. Second, items are managed in the Nvivo 12 plus software by classifying them by author, year, journal, and publisher name. Furthermore, this classification is performed using the NVivo 12 database import feature.

\section{RESULTS AND DISCUSSION}

In this study's results, journal analysis results by comparing the new public management policies in Developed and Developing Countries are the two data seen from 2016 to 2020 by comparing the number of documents published.

\section{Publication by Year}

Documents published in 2016 to 2020 discussing new public management policies in Developed and Developing Countries can be found because the number of papers published from the Scopus data is 473 documents for data on new public management policies in developed countries and developing countries documents namely 145 reports. It can be seen that there are more themes about new public service management policies in developed countries than in developing country documents. Papers published annually can be seen in the image below.

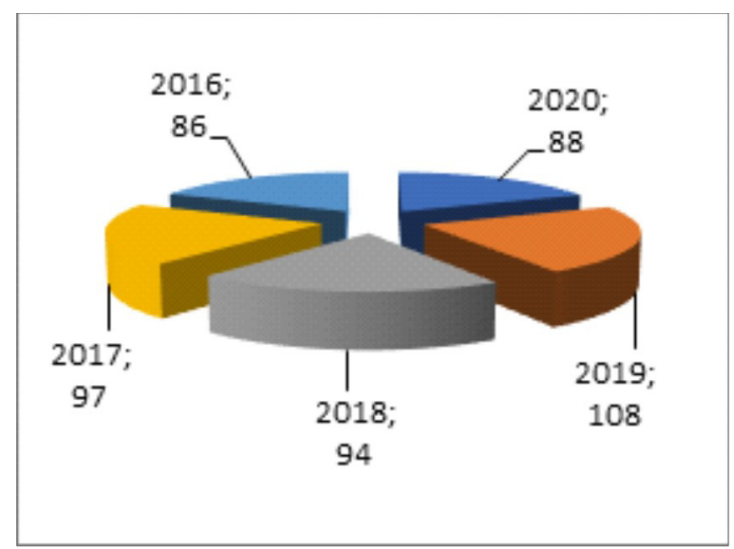

Figure 1. Developed Country Publications

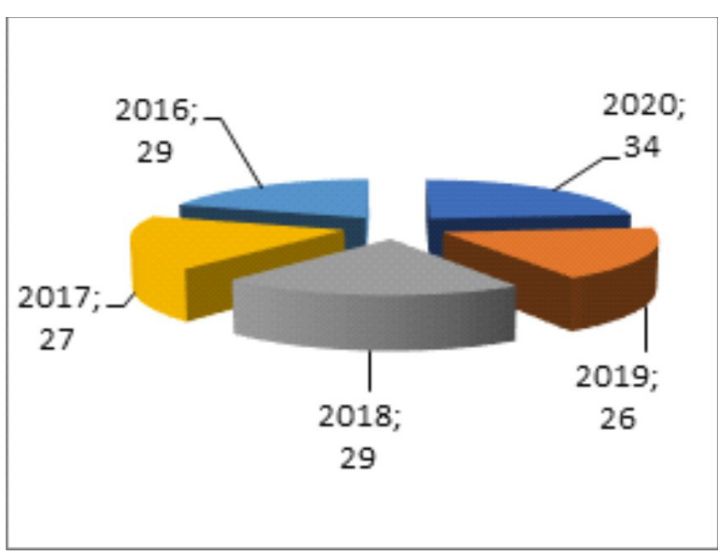

Figure 2. Developing Country Publications 
Document data per year is seen from Scopus data with new public management themes in developed country policies. There are 473 publications, the most publications were in 2019 with 108 documents, and the lowest was in 2020 with 88 papers. Meanwhile, on the theme of new public management in developing country policies from the Scopus analysis results in the last five years, there were as many as 145 documents. Most documents were in 2020 with 34 papers, and the lowest forms were obtained in 2019 with 26 articles. The data above shows that new public management in developing country policies has received more documents from 2015 to 2020 than new public management in developing countries. Although developed countries have the most publications, they will experience a decline in magazines in 2020. Meanwhile, publications in developing countries increased in 2020, and if the average publication is averaged each year, developing countries have productivity and publication development every year.

\section{Publication based Sources}

Based on the source documents taken from Scopus data, which talks about new public management in developed and developing countries, the author has five sources with the most publications during the 2016 to 2020 period. Can be seen in figures 3 and 4 below:

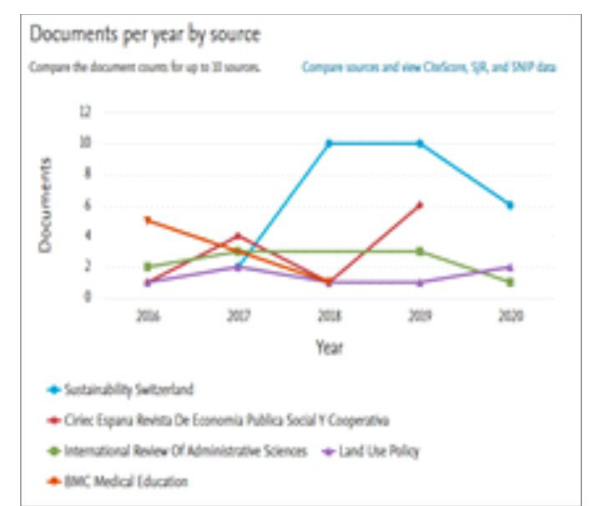

Figure 3. Developed Country

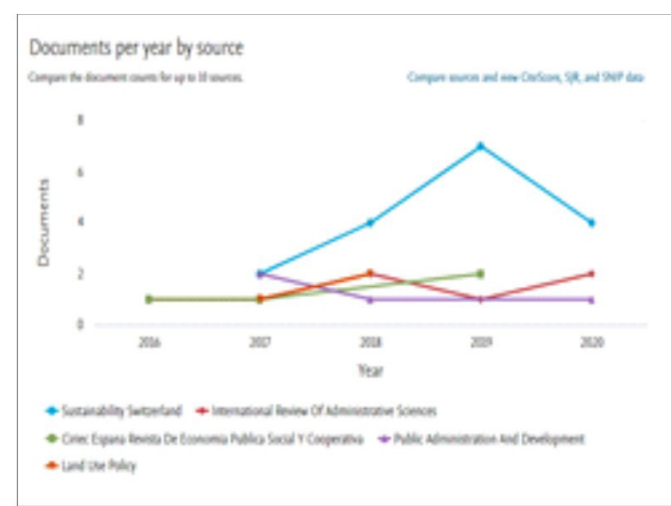

Figure 4. Developing Country

Based on the document source from the picture above, five most document sources publish new public management in developed countries: Sustainability Switzerland, Social, Ciriec Espana Revista De Economia Publica Y cooperative, International Review Of Administrative Sciences, Land use Policy, Bmc Medical. And the one that publishes the most is Sustainability Switzerland 28. Meanwhile, new public management in developing countries also has the top 5 publications, and the most published is Sustainability Switzerland, namely 17. Both developed and developing countries have the most publications based on the same source. 


\section{Publication by Country}

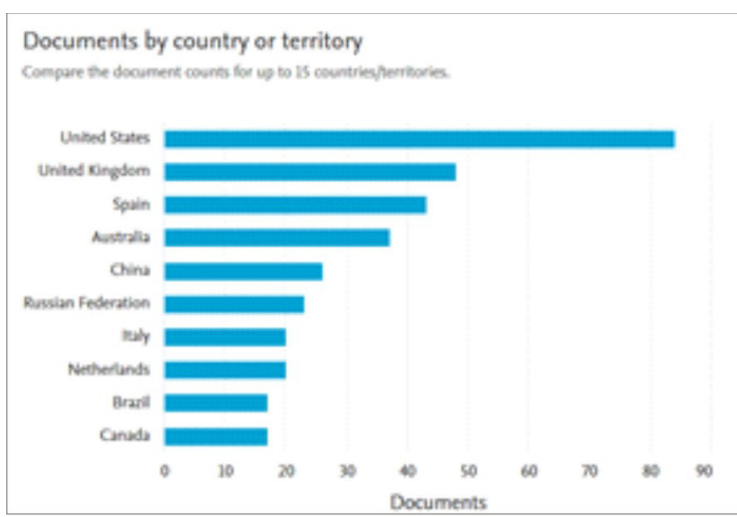

Figure 5. Publication by Developed Countries

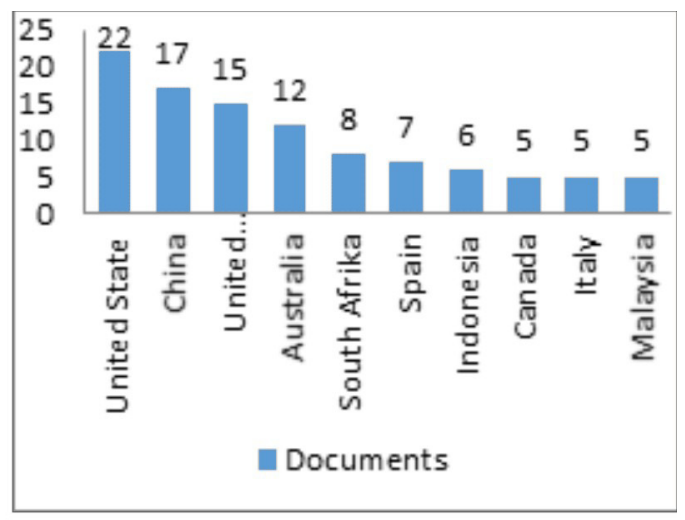

Figure 6. Publication by Developing Countries

The countries above provide information and understanding about new public management in developed and developing countries, as seen in the Scopus data from 2016 to 2020. The results found that ten countries publish a lot about new public management. The most documented developed countries are United States, United Kingdom, Spain, Australia, China, Russian Federation, Italy, Netherlands, Brazil, and Canada. Meanwhile, countries publish a lot about new public management in developing countries, namely: United States, China, United Kingdom, Australia, South Africa, Spain, Indonesia, Canada, Italy, and Malaysia. More details can be seen in figures 7 and 8 above. Various documents produced can be identified by document type, shown in Figure 8 and Figure 9 below.

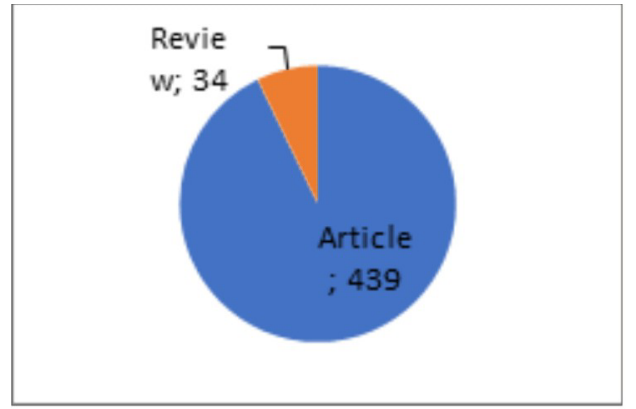

Figure 7. Developed Country by Document Type

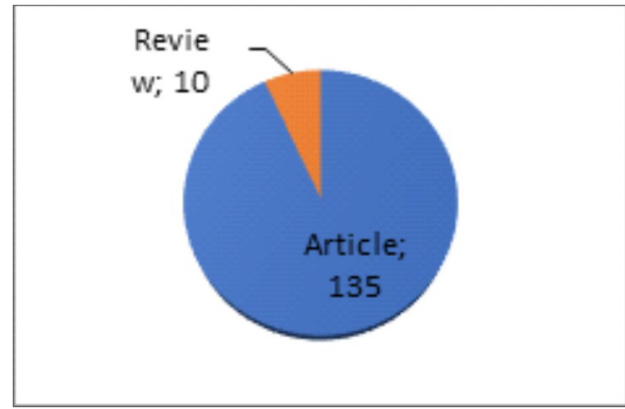

Figure 8. Developing Country by Document Type 
The amount of data generated from 2016 to 2020 from the Scopus results regarding new public management in developed countries and developing countries can be grouped by type of articles and reviews. . There are 473 types of data on new public services in developed countries, 439 for article types and 34 for review types. Meanwhile, the Scopus results on new public services in developing countries produce document types grouped into two documents: article and review. The types of items made are 135 documents, and article types are ten documents. Article documents on document types dominate in providing information and knowledge about new public services in developed and developing countries. The two figures can be seen from the comparison that the article that discusses new general management in developed countries is more of an item than articles with new public service themes in developing countries.

\section{Network Visualization New Public Service Policy Themes in Developed Countries}

This section will explain the development of studies on new public service policies in developed countries with 473 documents. Then the researcher will explain new public service policies in developing countries with 145 papers. Using VOSviewer, which can show the development of the theme discussed. This finding is essential in providing new products and finding novelty in research in new service policies in developed and developing countries. In Figure 9, you can see the development of new public service policies in developed countries from the 2016 to 2020 Scopus results.

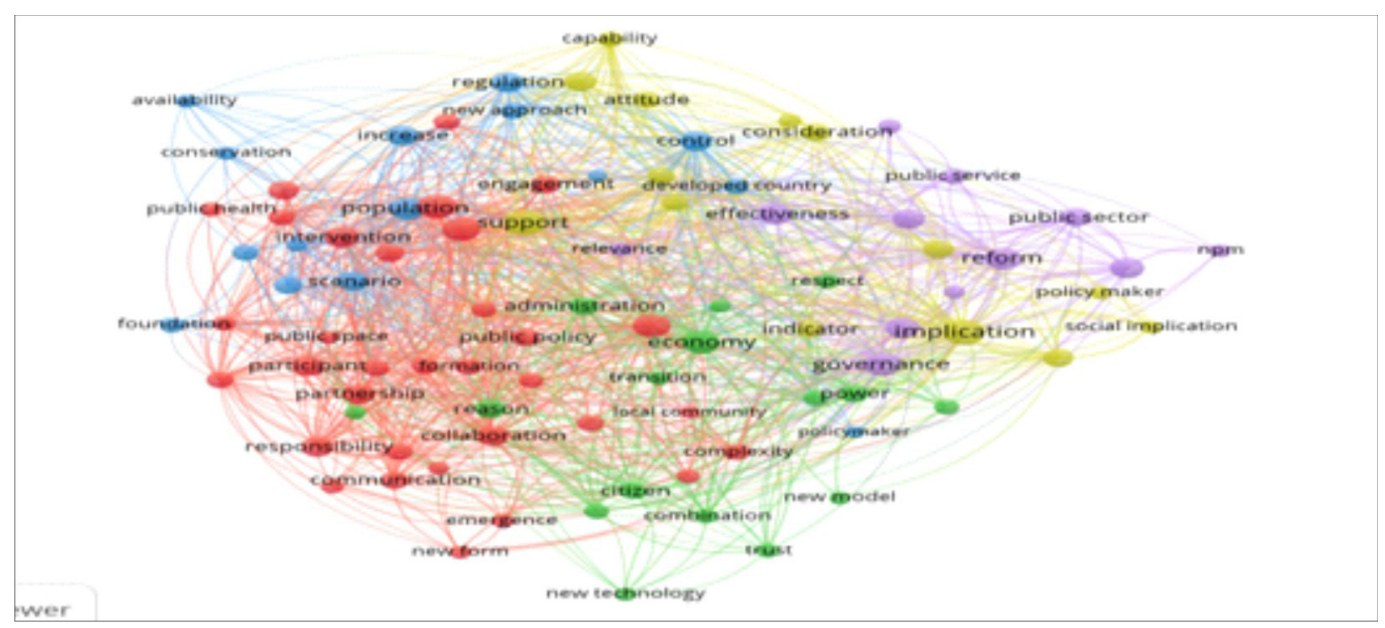

Figure 9. Visualization of The Network Map for The Development of New Public Management Policy Research in Developed Countries

Updating information on developing new public service policy research trends in developed countries by understanding the VOSviewer image's correlation can be classified into 5 clusters. Cluster 1 focuses on Achievement, assessment, association, building, 
collaboration, collection communication, complexity, constraint, cooperation, course, decision-maker, and dynamic emergence. Cluster 2 focuses on Administration, citizen, combination, economy, evolution, new models, new technology, power, private sector, public outrage, territory, transition, transparency, trust. Custer 3 discusses Availability, charge, conservation, control, developing country, distribution, foundation, increase, investment, a new approach, policymaker, population, regulation, and scenario. Cluster details can be seen in Table 1 below.

Table 1. Themes of New Public Management Policies in Developed Countries

\begin{tabular}{|c|c|c|}
\hline Cluster & Concept Name & Total \\
\hline Cluster 1 & $\begin{array}{l}\text { Achievement, assessment, association, building, } \\
\text { collaboration, collection communication, } \\
\text { complexity, constraint, cooperation, course, } \\
\text { decision-maker, dynamic emergence, engagement, } \\
\text { facility, formation, integration, intervention, } \\
\text { involvement, local community, new form, outcome, } \\
\text { participant, partnership, planning, possibility, } \\
\text { priority, public policy. }\end{array}$ & 33 \\
\hline Cluster 2 & $\begin{array}{l}\text { Administration, citizen, combination, economy, } \\
\text { evolution, new model, new technology, power, } \\
\text { private sector, public authority, territory, transition, } \\
\text { transparency, trust. }\end{array}$ & 16 \\
\hline Cluster 3 & $\begin{array}{l}\text { Availability, charge, conservation, control, develop } \\
\text { country, distribution, foundation, increase, } \\
\text { investment, a new approach, policymaker, } \\
\text { population, regulation, scenario. }\end{array}$ & 15 \\
\hline Cluster 4 & $\begin{array}{l}\text { Attitude, behavior, capability, consideration, } \\
\text { decision making, implication, indicator, leadership, } \\
\text { policymaker, practical sense, practitioner, } \\
\text { requirement, social significance, support. }\end{array}$ & 14 \\
\hline Cluster 5 & $\begin{array}{l}\text { Effectiveness, efficiency, governance, local } \\
\text { government, new public management, npm, public } \\
\text { Administration, general management, public sector, } \\
\text { public service, reform, relevance. }\end{array}$ & 12 \\
\hline
\end{tabular}

For Cluster 1 related to new public management policies in developed countries, this article discusses Achievement, assessment, association, building, collaboration. Developed countries' new public management policies talk about values, achievements, associations, development, and collaboration. This illustrates that the new public management in 
developed countries assesses the government's public sector performance.

\section{Network Visualization New Public Management Policy Themes in Developing Countries}

This section describes concepts in several visualizations related to this research theme, and 56 of them were identified in 145 articles. Furthermore, the review results on VOSviewer reveal four groups of new public service policy concepts in developing countries, which can be seen in Figure 10. Shows the names of the ideas derived from the cluster density display. Furthermore, each color code is used to see a list of concepts that stand out from each cluster. The aim is to identify as many themes as possible that are often discussed in previous research and be used in future research. Looking at Figure 10, it can be seen that a different color distinguishes the cluster density from each cluster.

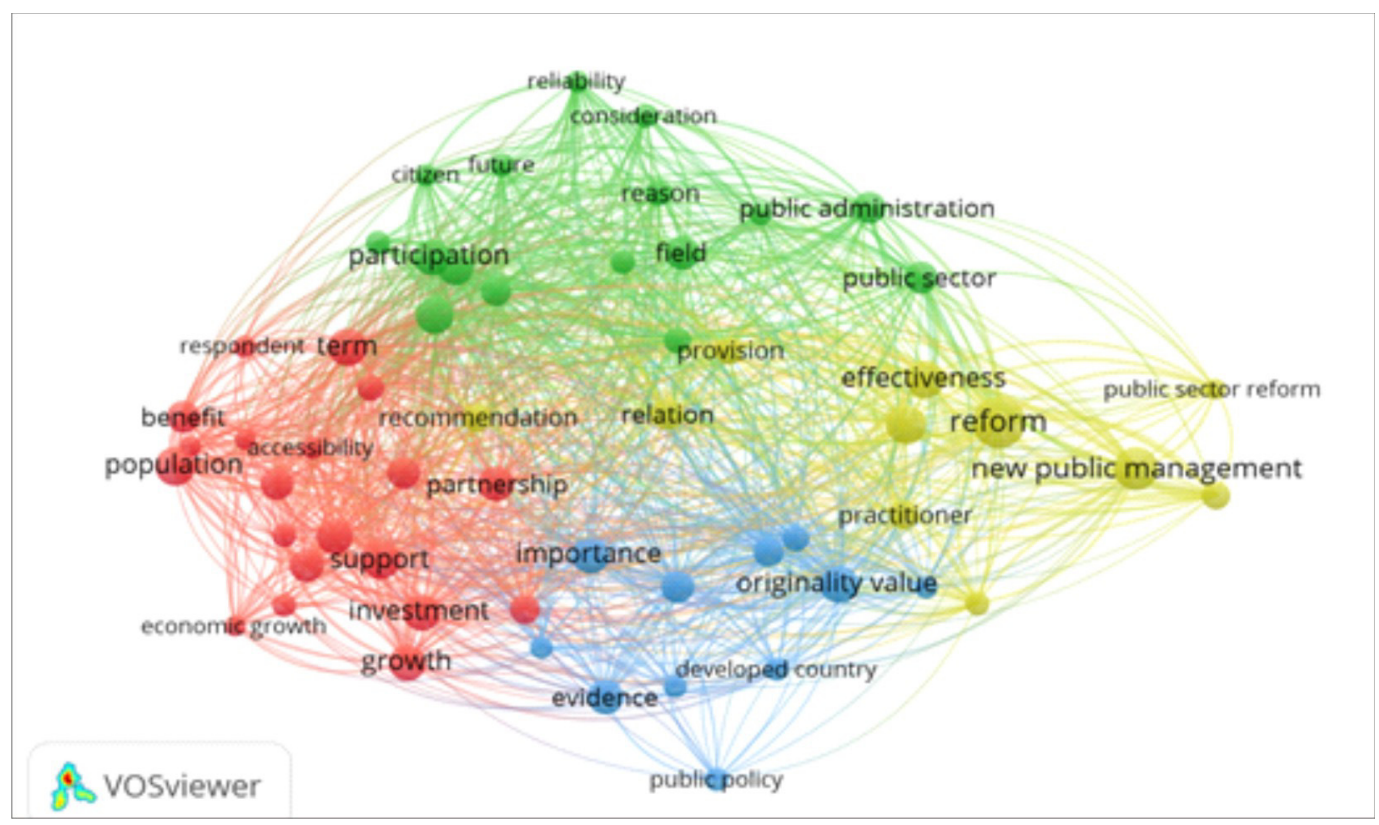

Figure 10. Themes Clustering of New Public Management Policies in Developing Countries

Identification in the form of a map in Figure 10 can help researchers, especially those who are just starting their research from scratch. When they find a topic of interest in a particular area they are interested in, they can read articles related to that topic with this study's help. In Cluster 1, the related concepts are accessibility, benefit, cause, demand, economic growth, growth, infrastructure, integration, investment, majority, partnership, panning, population, public health, respondent, responsibility. In contrast, Cluster 2 emphasizes the concept of adaptation, citizen. Consequence, consideration, field, future, 
improvement, limitation, organization, public, public Administration, public sector, reason, reliability, society. In Cluster 3, the concepts are aimed at accountability, collaboration, developed country, evidence, implication, importance, originality value, practical implication, private sector, public policy, and cluster. For researchers who wish to discuss new public service policy themes in developing countries, this clustering will help analyze the related concepts. For example, when the researcher chooses cluster 4, the starting point that needs to be used as body literature is the concept of Adoption, effectiveness, efficiency, new public management, NPM, practitioner, provision, public sector reform, recommendation, reform, relations. Researchers can also search for literature related to reference managers, with keywords included in the cluster 4 category: Adoption, effectiveness, efficiency, new public management, npm, practitioner, provision, public sector reform, recommendation, reform, and relations. Others. Several general management elements, such as decentralization, market-based services, efficiency, and accountability, need to be reformed first through NPM practices to create a suitable promotion basis (Wahed Waheduzzaman, 2019).

Table 2. Themes of New Public Management Policies in Developing Countries

\begin{tabular}{|c|c|c|}
\hline Cluster & Concept Name & Total \\
\hline Cluster 1 & $\begin{array}{l}\text { Accessibility, benefit, cause, demand, economic } \\
\text { growth, growth, infrastructure, integration, } \\
\text { investment, majority, partnership, panning, } \\
\text { population, publich health, respondent, } \\
\text { responsibility, support, sustainability, term, } \\
\text { urbanization }\end{array}$ & 20 \\
\hline Cluster 2 & $\begin{array}{l}\text { Adaptation, citizen, consequence, consideration, } \\
\text { field, future, improvement, limitation, organization, } \\
\text { public, public Administration, public sector, reason, } \\
\text { reliability, society, }\end{array}$ & 16 \\
\hline Cluster 3 & $\begin{array}{l}\text { Accountability, collaboration, developed country, } \\
\text { evidence, implication, importance, originality value, } \\
\text { practical implication, private sector, public policy, }\end{array}$ & 11 \\
\hline Cluster 4 & $\begin{array}{l}\text { Adoption, effectiveness, efficiency, new public } \\
\text { management, npm, practitioner, provision, public } \\
\text { sector reform, recommendation, reform, relation. }\end{array}$ & 11 \\
\hline
\end{tabular}




\section{Dominant Themes in Policy Studies New Public Management in Developed} and Developing Countries

Word Frequency Queries explores the words that appear most frequently in research data. Therefore, this analysis tool talks with the same meaning can be categorized into one group. Based on data analysis results on new public service policy documents in developed countries, sourced from 473 articles, previous researchers' dominant theme is themes related to public, management, social policy, development, new, urban, education. Meanwhile, developing countries' article about new public services is management, development, new, policy, health, government, Administration, and urban. Therefore, it can be interpreted that this is the overall focus of research related to this topic. This is further explained in (Figures 11 and 12), especially in bold words.

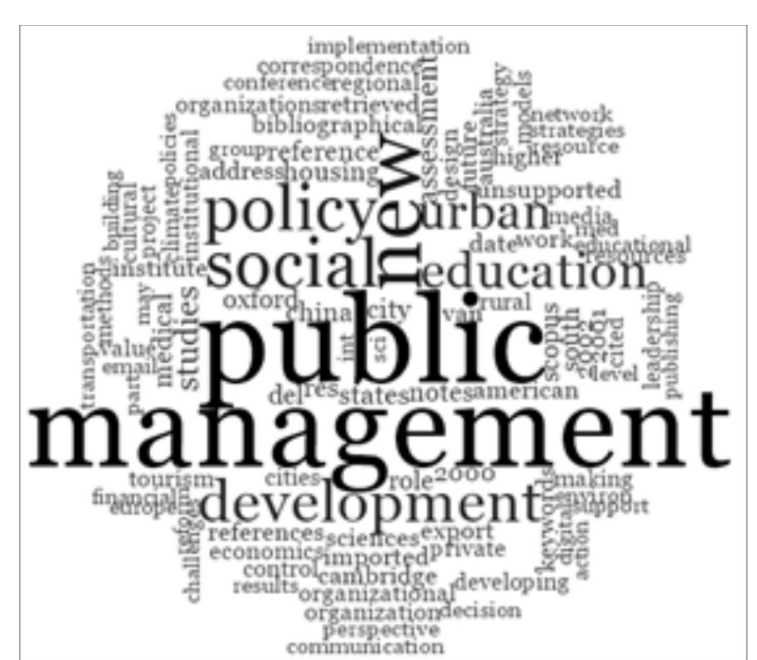

Figure 11. Dominant Themes in New Public Management Studies In Developed Countries

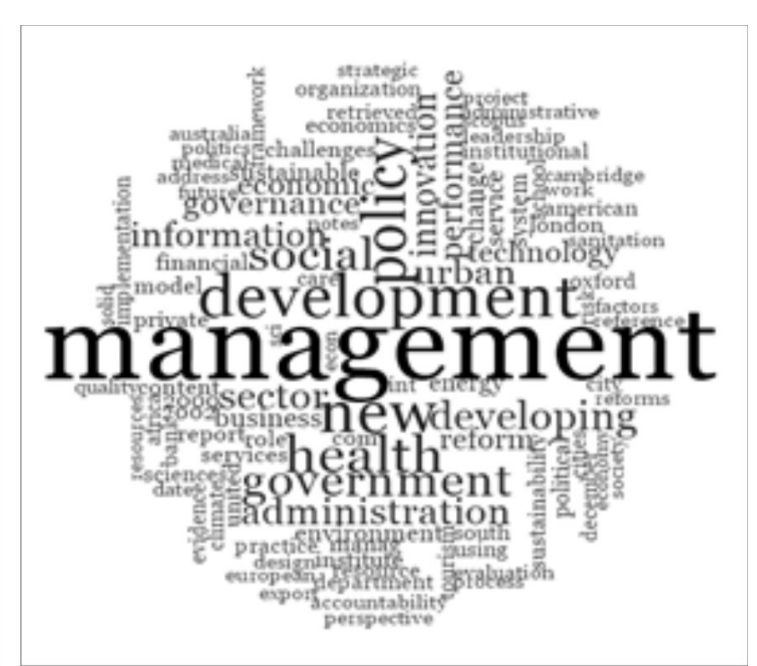

Figure 12. Dominant Themes in New Public Management Studies In Developing Countries

\section{The Categorization of New Public Service Policies in Developed} and Developing Countries Themes

Based on cluster analysis with NVivo 12 plus sourced from 473 Scopus indexed articles, there are twelve main clusters in new public management policy studies in developed countries (see Figure 13), namely. Furthermore, the results of the Categorization of research themes indicate that research on new public management policies discusses many articles about public, management, policy, development, systems, social, sector, technology, urban, government, change, and governance. 


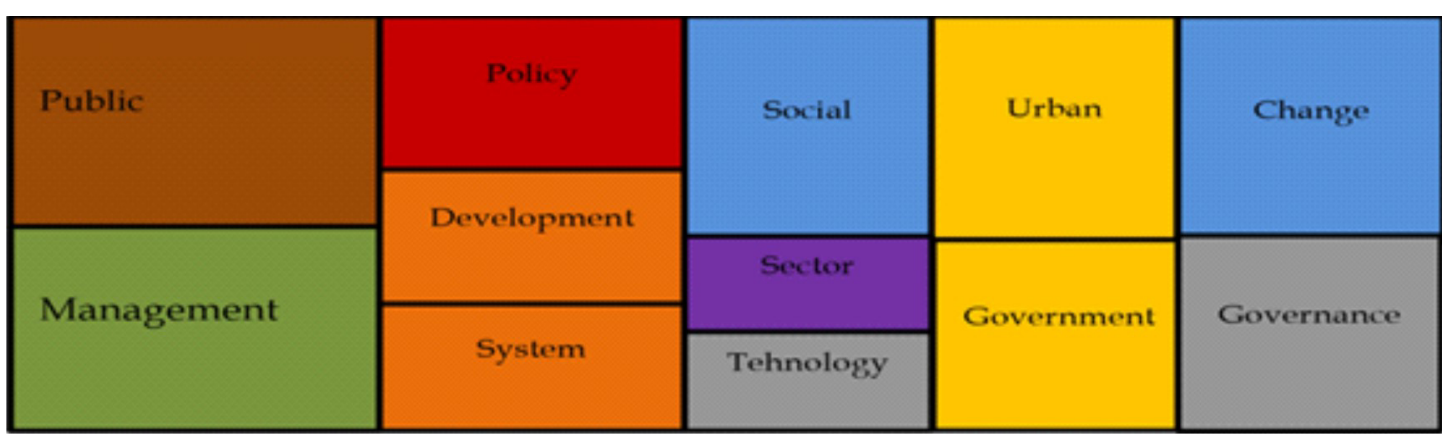

Figure 13. The Categorization of New Public Service Policy Themes in Developed Countries

Furthermore, based on cluster analysis with NVivo 12 plus sourced from 145 Scopus indexed articles, there are thirteen main clusters in new public management policy studies in developing countries (see Figure 14). Furthermore, the Categorization results of research themes show that research on new public management policies in developing countries discusses many articles about public, development, management, policy, reform, government, local, sector, governance, innovation, urban, and sustainability.

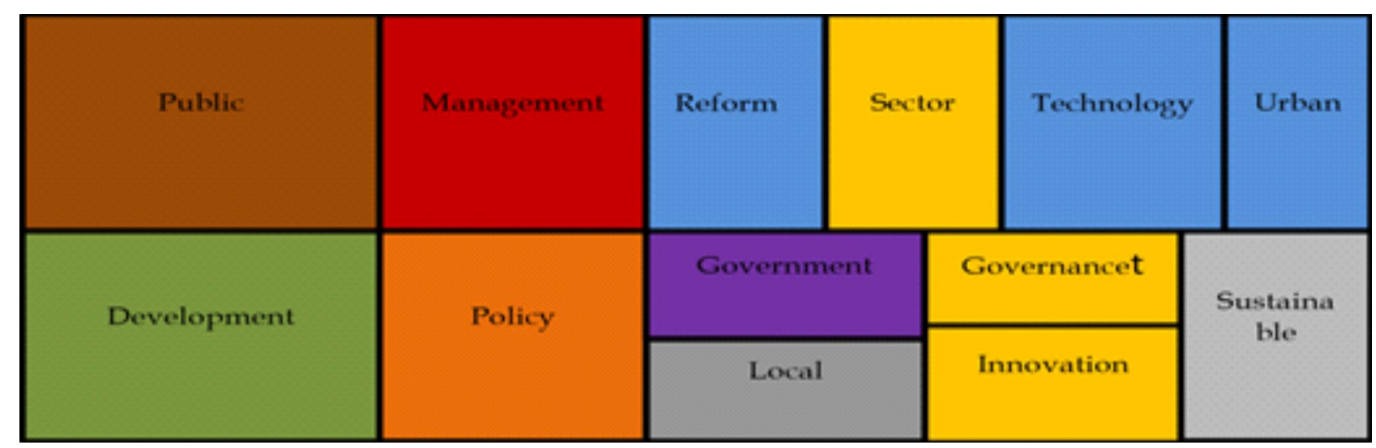

Figure 13. The Categorization of The Theme of New Public Service Policies in Developing Countries

\section{The Relationship Between the Topics of New Public Service Policies in Developed Countries}

The results of the study from Scopus contained 473 articles which were then processed using NVIVO 12 plus showing that there is a strong relationship between new public policy topics in developed countries with the public, management, policy, development, systems, social, sector, technology, urban, government, change, and governance. Although this relationship has different Jaccard coefficient values between the new public management policies and the twelve study topics, it is confirmed that this study cannot 
be separated from the public, management, policy, development, and several others. Meanwhile, new public management policies in developing countries obtained from 145 Scopus data, which were also processed using NVIVO 12 plus, showed a strong relationship between new public management policies in developing countries and the public, management, policy, reform, government. , local, sector, governance, innovation, urban, and complete sustainability can be seen in the following table:

Table 3. New Public Management Relations in Developed Countries

\begin{tabular}{clc}
\hline \multicolumn{1}{c}{ Code A } & Code B & Jaccard's Coefficient \\
\hline policies in developed countries & Public & 0,82237 \\
policies in developed countries & Management & 0,82237 \\
policies in developed countries & Policy & 0,05128 \\
policies in developed countries & Development & 0,06154 \\
policies in developed countries & System & 0,07317 \\
policies in developed countries & Social & 0,66667 \\
policies in developed countries & Sector & 0,16667 \\
policies in developed countries & Technology & 0,21782 \\
policies in developed countries & Urban & 0,66667 \\
policies in developed countries & Government & 0,33333 \\
policies in developed countries & Governance & 0,20395 \\
policies in developed countries & Change & 0,33333 \\
\hline
\end{tabular}

In the table above we can see the relationship between new public management in developed countries and the public, management, policy, development, have a strong relationship in new public management in developed countries. Therefore, in developed countries, new public management requires a new system of services, namely by using technology. Technology is used as a renewal in new public services. The use of technology in services is not just following global trends, but is directed at realizing good governance, namely good governance, transparency and accountability in government processes. 
Table 4. New Public Management Relations in Developing Countries

\begin{tabular}{llc}
\hline \multicolumn{1}{c}{ Code A } & Code B & Jaccard's coefficient \\
\hline policies in developing countries & Public & 0,551724 \\
policies in developing countries & Development & 0,025641 \\
policies in developing countries & Management & 0,025641 \\
policies in developing countries & Policy & 0,032258 \\
policies in developing countries & Reform & 0,006897 \\
policies in developing countries & Government & 0,365517 \\
policies in developing countries & Local & 0,142857 \\
policies in developing countries & Sector & 0,373333 \\
policies in developing countries & Innovation & 0,125 \\
policies in developing countries & Governance & 0,084746 \\
policies in developing countries & Tehnology & 0,025641 \\
policies in developing countries & Urban & 0,142857 \\
policies in developing countries & Sustainable & 0,142857 \\
\hline
\end{tabular}

The table above explains the relationship between code A and code B (new public management in developing countries), which has a relationship between public, development, and management by looking at the percentage of Coefficient jaccards. The relationship between this concept, the writer sees the relationship with the highest percentage in the concept of public services, namely the public itself and the government.

The relationship between the concepts of developed countries and developing countries has almost the same concept. Developed countries in the public sector have a presentation of 0.82237 , while developing countries in the public sector have a percentage of 0.551724 . On the other hand, when we want to see the difference, developed countries in the Government section have a 0.33333 while developing countries in the government section have a percentage of 0.365517 . In the second concept above, which has several components almost the same in presentation, what distinguishes the two concepts above lies in the concept of reform (Reformasi). New public management in developing countries is still discussing reform, while in developed countries, it is not discussing the concept of reform. 


\section{CONCLUSIONS}

Based on the discussion results in comparing the concepts of new public management policies in developed and developing countries. The following conclusions can be drawn:

1. The development of research that discusses new management policies in developed countries from 2016 to 2020 is considered very large, with 473 documents published in several journal sources. This study found that the journal source published the most related to new public management was the Swiss Sustainability journal, with 28 documents. The country that contributed the most was the United States. The document types are article types, 439 papers, and 34 document reviews. The results of the study with VOSviewer show that there are five concepts in new public management policies in developed countries, namely In cluster 1, it focuses on Achievement, assessment, association, building, collaboration, collection communication, complexity, constraint, cooperation, course, decision-maker, dynamic emergence. Cluster 2 focuses on Administration, citizen, combination, economy, evolution, new models, new technology, power, private sector, public outrage, territory, transition, transparency, trust. Custer 3 discusses Availability, charge, conservation, control, developing country, distribution, foundation, increase, investment, a new approach, policymaker, population, regulation, and scenario. The reader can see in full the five clusters regarding new public management policies in developed countries in table 1 . Besides, previous researchers' dominant themes are grouped into eight main categories: public, management, social policy, development, new, urban, education. Furthermore, the Categorization of research themes shows that research on new public management policies in developed countries discusses many articles about public, management, policy, development, systems, social, sector, technology, urban, government, change, and governance.

2. Discussion of new public management policies in developing countries found 145 documents published from 2016 to 2020 . The journal source published the most about new general management policies in developing countries was Sustainability Switzerland, namely 17. Furthermore, the country that contributed the most documents was the United States, with 22 papers. The types of documents were: The articles produced were 135 documents, and the review was ten documents. The review results with VOSviewer show four concepts in new public management policies in developing countries. In Cluster 1, the related ideas are accessibility, benefit, cause, demand, economic growth, growth, infrastructure, integration, investment, majority, partnership, panning, population., public health, respondent, responsibility, while Cluster 2 emphasizes adaptation, citizen, consequence, consideration, field, future, improvement, limitation, organization, public, public Administration, public sector, reason, reliability, society. In the case of Cluster 3, the concept is aimed at accountability, collaboration, developed country, evidence, implication, importance, 
originality value, practical implication, private sector, public policy, and cluster 4 emphasizes the concept of Adoption, effectiveness, efficiency, new public management, $\mathrm{npm}$ - practitioner, provision, public sector reform, recommendation, reform, relations. Besides, previous researchers' dominant themes were grouped into eight main categories: management, development, new, policy, health, government, Administration, and urban. Furthermore, the Categorization results of research themes show that research on new public management policies in developing countries discusses a lot about the themes of public, development, management, policy, reform, government, local, sector, governance, innovation, urban, and sustainable.

These two comparisons illustrate the development of new public management policies in developed and developing countries. They can provide related information about the concept of new public management policies in both developing and developed countries. new In this study only looks and compares the analysis results of developments and the concept of new public management policies. So that the recommendations for further research are to be able to compare new public management policies in developed and developing countries in certain management sectors, for example, new public management policies in the education, health, economic sectors and also share other aspects that can be seen and in future research can compare sources data published by Scopus data with web of science (Wos) data.

\section{REFERENCES}

Alamsyah, A. (2016). Perkembangan Paradigma Administrasi Publik (New Public Administration, New Public Management dan New Public Service). Jurnal Publik Profetik, 04(2), 172-199. https:// doi.org/https://doi.org/10.24252/ profetik.v4i2a4

Anglada-Tort, M., \& Sanfilippo, K. R. M. (2019). Visualizing Music Psychology: A Bibliometric Analysis of Psychology of Music , Music Perception , and Musicae Scientiae from 1973 to 2017 . Music E Science, 2, 205920431881178. https://doi.org/10.1177/ 2059204318811786

Apriliyanti, I. D., \& Alon, I. (2017). Bibliometric analysis of absorptive capacity. International Business Review, 26(5), 896-907. https://doi.org/10.1016/j.ibusrev.2017.02.007

Cumming, D. J., \& Johan, S. A. (2019). Crowdfunding: Fundamental cases, facts, and insights. In Crowdfunding: Fundamental Cases, Facts, and Insights. College of Business, Florida Atlantic University, Boca Raton, FL, United States: Elsevier. Retrieved from https:/ / www.scopus.com/inward/ record.uri?eid=2-s2.0-85094672929\&partnerID= 40\&md5=4dcfa5bcadb7c2bee3014add911e337f 
Habibi, F. (2020). Pemetaan Riset Reformasi Birokrasi di Indonesia. Jurnal Borneo Administrator, 16(2), 199-230. https://doi.org/10.24258/jba.v16i2.695

Heidari, R., Yazdanparast, R., \& Jabbarzadeh, A. (2019). Sustainable design of a municipal solid waste management system considering waste separators: A real-world application. Sustainable Cities and Society. Retrieved from https://www.scopus.com/ inward / record.uri?eid=2-s2.0-85061549805\&doi=10.1016\%2Fj.scs.2019.101457\& partnerID=40\&md5=b5a38d9d928706bc2dd65cef30702fa8

Hood, C., \& Dixon, R. (2015). Commentary What We Have to Show for 30 Years of New Public Management/ : Higher Costs , More Complaints. 28(3), 265-267. https://doi.org/ 10.1111 /gove.12150

Ikeanyibe, O. M. (2016). New Public Management and Administrative Reforms in Nigeria. International Journal of Public Administration. Retrieved from https:/ / www.scopus.com/ inw ard / record.uri?eid=2-s2.0-84948823647\&doi=10.1080\% 2F01900692.2015. 1023446\&partnerID=40\&md5=fea57f66bbd6f43cf39ea06dc51b25c7

Kharisma, B. (2014). Dalam Sektor Publik Dan Swasta ( Suatu Pendekatan Ekonomi Kelembagaan ). Jurnal Buletin Studi Ekonomi, Vol., Vol. 19(1), 9-30.

Lim, W.-S., Liang, C.-K., Assantachai, P., Auyeung, T. W., Kang, L., Lee, W.-J., ... Arai, H. (2020). COVID-19 and older people in Asia: Asian Working Group for Sarcopenia calls to actions. Geriatrics and Gerontology International.

Mørk, A. (2020). From boots on the ground to followers in the sky: Volunteer mobilization and populist rhetoric in the presidential campaigns of Barack Obama and Donald Trump. American Studies in Scandinavia, 52(2), 183-210. Retrieved from https:// w w w. s c opus. c o m / i n w a rd/ r e cord.uri ? e i d = 2-s 2 . 0 85095125973\&partnerID=40\&md5=e787263c0ff1ededc43fd4f7b066c8c9

Oscar Basulto, G., Pablo Segovia, L., \& Cristián Jullian, S. (2020). Social imaginaries and representations regarding 2011's student movements: Towards a configuration of a media profile of the El Mercurio S.A.P. group | Imaginarios y representaciones para configurar un perfil mediático de la prensa tradicional en Chile: E. Universum, 35(1), 250-287. https:// doi.org/10.4067/S0718-23762020000100250

Pedersen, J. S., \& Wilkinson, A. (2018). The digital society and provision of welfare services. International Journal of Sociology and Social Policy. Retrieved from https:// w w w. s copus. com/in w a rd/ r e cord.uri ? e i d = 2-s 2 . 0 $85043379855 \& \mathrm{~d}$ o i $=10.1108 \% 2$ F I J S S P - $05-2017$ 0062\&partnerID=40\&md5=f3c36ea7d4766b1ab9b5fdcaa0474497

Prabowo, T. J. W. (2018). Reforms in public sector accounting and budgeting in Indonesia (2003-2015): Confusions in implementation. Journal of Public Budgeting, Accounting and Financial Management. Retrieved from https://www.scopus.com/inward/ record.uri? eid=2-s2.0-85044256744\&doi=10.1108\% 2FJPBAFM-03-2018002\&partnerID $=40 \& m d 5=1$ e3966ad09e44a6c2d3e23796819e6c2 
Raharjanto, T. (2019). Systematic Literature Reviews: Sistem Merit Dalam Manajemen Sumber Daya Manusia Sektor Publik. Jurnal Pemerintahan Dan Keamanan Publik (JP Dan KP), 1(2), 103-116.

Rosyadi, S., \& Dharma, S. (2014). New Public Management Practices at Local Government in Indonesia: A Case Study of Wonosobo Government, Central Java. (Icpm), 46-51. https:/ / doi.org/10.2991/icpm-14.2014.8

Rushananto. (2014). Kebijakan Publik. Kebijakan Publik, (1993), 15.

Tampubolon, M. P. (2020). Change Management Manajemen Perubahan/: Individu, Tim Kerja Organisasi. Penerbit Mitra Wacana Media.

Taufiqurokhman, \& Satispi, E. (2018). Teori Dan Perkembangan Manajemen Pelayanan Publik. Umj Press 2018, 266.

Waheduzzaman, W. (2019). Challenges in transitioning from new public management to new public governance in a developing country context. International Journal of Public Sector Management. Retrieved from https://www.scopus.com/inward/ record.uri? eid=2-s 2.0-85073697776\&d oi=10 .1108\% 2FIJPSM-02-20190057\& partnerID $=40 \& m d 5=a 4367 b 44 a 85 f b e 960 b 997 \mathrm{db} 822 \mathrm{ccdc} 52$

Waheduzzaman, Wahed. (2019). Challenges in transitioning from new public management to new public governance in a developing country context. International Journal of Public Sector Management, 32(7), 689-705. https://doi.org/10.1108/IJPSM02-2019-0057

Zhong, L., \& Fisher, K. R. (2017). Participation and Chinese non-government organization accountability. International Journal of Sociology and Social Policy. Retrieved from https:/ / w w w. scopus. com/inw ard/ r e cord.uri ? e id = 2-s 2 . 0 $85035136921 \&$ d o i $=10$. $1108 \% 2$ F I J S S P - $08-2015$ 0086\&partnerID $=40 \& m d 5=771 \mathrm{f} 2 \mathrm{ada} 92177 \mathrm{a} 7 \mathrm{e} 02 \mathrm{~b} 29815 \mathrm{a} 19385 \mathrm{a} 8$ 